\title{
Liberal Constitutional Democracies in Times of Crisis
}

\section{Corradetti ${ }^{1}$}

Published online: 28 February 2022

(c) The Author(s), under exclusive licence to Springer Nature Switzerland AG 2022

The proliferarion of democracies has seen a dramatic explosion starting from the end of World War II up to present days. If in 1945 there were only 12 constitutional democracies worldwide, by 2003 that number rose to $121 .{ }^{1}$ By the end of the twentieth century, liberal constitutional democracy appeared to be the exclusive and undiscussed game in town.

Despite the proliferation of democracies today, liberal constitutional and democratic crises highlight a fundamental structural problem, particularly in the interaction between the level of juridical architecture and that of political praxis. As it appears, the hierarchical subordination of legitimate politics to a liberal constitutional framework has been subverted.

Certainly, there is no constitution that works for all seasons. Aristotle believed that the task of (political) science was not just to seek the ideal constitution, but rather to understand "the one that is best in the circumstances" 2 of a given case. Constitutions change and they have changed enormously from ancient times till today. ${ }^{3}$ Thomas Jefferson believed that constitutions had to be redone every 19 years, yet paradoxically, the American Constitution of 1789 is the only one that has remained in place despite being amended 27 times.

\section{Stepping Stones of Liberal Constitutionalism}

Contemporary constitutions originate from the historical events of the American and French Revolutions. They emanate from a sovereign people constituting a legal regime under whose law all are bound. It was in this time that Sieyès introduced the fortunate distinction between pouvoir constituant and pouvoir constitué. While the constituting notion of power points to the law-creating force by a collective will (the

\footnotetext{
1 See Loughlin (2019), 436.

2 Aristotle (1998) [IV sec.], 101.

3 See also McIlwain (1947); Grimm (2016), 3-40.

C. Corradetti

Claudio.Corradetti@uniroma2.it

1 University of Rome Tor Vergata, Rome, Italy
} 
constitution properly said), what is constituted is the administrative power and the legislative organs for statutory law. On the one hand, the constituting process formulates a law binding public institutions; on the other hand, the constituted powers formulate and apply the law to the people as a whole. The constituting phase takes priority over the day-to-day ordinary administration of the law. Whereas constituting norms cannot be changed in ordinary terms, contractual law varies with political legislatures (constitutional vs regulatory/contractual law). This process reveals the reflexive character of constitutional regimes insofar as here the law is applied to law. ${ }^{4}$

Historically, Western constitutionalism has undergone the legal positivization of the universal principle of human rights. Accordingly, the constituting force of the people has transferred these values into the constituted regime and the exercise of public powers has been subjected to the respect of a bulk of human rights. The narrative concerning the rapid spread of the philosophical principles of human rights into the revolutionary constitutions of America and Europe testifies to the peculiarity of the modern constitutional state.

The definition of what is a constitution has moved from a descriptive to a normative sense. According to ancient conceptions, constitutions are to be considered in empirical terms, whereas in the modern sense, constitutions reflect a rather normative idea - a constituent people endowed with fundamental rights and political representation. ${ }^{5}$ In this respect, the long-lasting philosophical reflection on contract theory fulfilled a normative understanding for the unity of people.

Even if constitutions change, legitimate modifications undergo a demanding set of majoritarian requirements. Hierarchy and legitimate law enactment merged together after they had previously existed separately. ${ }^{6}$ No one could place himself above the law-not the people, not public officials, and not religious confessions. This marked a profound separation from the XVII century Hobbesian theory of power.

Yet, it was only following preoccupations for social justice and equality that Lockean constitutionalism was transformed into a model closer to contemporary constitutional understandings. Later, with Rousseau, the task of political justice included also the preoccupation for equalizing opportunities for the rich and the poor.

When precisely did the programmatic transformative ideal of liberal constitutionalism tilt? How do we reconsider and clarify the nexus political-constitutional, that is, political praxis as a realization of programmatic constitutional ideals?

When one reads about Musk and Bezos competing for space's colonization, the question arises naturally whether political justice is, in fact, still a relevant societal preoccupation today. Class struggle no longer occurs between an impoverished bourgeoisie and an even more impoverished proletariat; it is rather between the (very) rich and the (very) poor. By that I mean groups of people either capable of affording the dream to buy a ticket to travel to space or struggling to pay a monthly card for public transportation. This scenario is the result of a long-lasting phase of liberal

\footnotetext{
4 Grimm (2016), 334.

5 On this distinction see also Grimm (2016), 44.

${ }^{6}$ See Grimm (2016), 12.
} 
constitutional transformations. I consider this result as a paradoxical outcome which runs against the inspiring values of modern constitutionalism. This ruling model originated from a socially widespread sense of equality (at the end of medieval society) and it affirmed itself during the mercantilist bourgeoisie in the XVII century.

It is of the contemporary failure to comply with the original missions of liberal constitutionalism as a model of historical emancipation that we need to account for today.

\section{More Democracies, Less Democracy?}

Besides the relevance on the origin and recent dynamics of development of liberal constitutionalism, it appears appropriate to consider the dimension of the democratic exercise of power under a constitutional regime.

Let's start by answering some fundamental questions.

- What are liberal constitutional democracies? How do they differ from non-liberal democracies?

Liberal constitutional democracies began consolidating in the mid-1990s on the basis of three criteria: elections, freedom of speech, and freedom of association. ${ }^{7}$ The combination of these three factors promoted a certain perspective on the relation between the citizens and the government, one based on the assumption that institutionally organized collective freedom (democracy) should reflect the public views of its members insofar as they fall within the limits imposed by human rights constraints. Neo-constitutionalism after WWII incorporated fundamental rights within constitutional charters. Fundamental rights provided an embedded form of constitutional freedoms and values.

- What crises are we facing today? Are they a sort of democratic deficit crises? Are they instead a type of parliamentary crises? ${ }^{8}$

First, constitutional crises should not be confused with the use of emergency powers such as those described by Schmitt in analogy to the commissarial dictatorship of antiquity and reflected in the constitutional use of art.48 of the Weimar Constitution. Furthermore, speaking of deficit crises means to refer to three types of phenomena: (a) the explicit refusal of public officials to disobey the constitution, (b) the capacity of constitutions to prevent a looming disaster, and (c) consistent disobedience by the people.

Secessions include types (a) and (c) as in the case of the Civil War. ${ }^{9}$

Today's constitutional crises are not yet at this stage of severity. Egypt and Turkey, for instance, show a trend towards a withdrawal from constitutional guarantees but not yet a radical collapse of the social democratic texture. Certainly, reports

\footnotetext{
7 Ginsburg and Huq (2018), 36.

8 Schmitt (1988) [1923].

9 Balkin (2018), 14.
} 
from Freedom House show a drastic decline in the number of liberal democracies after $2010,{ }^{10}$ as well as a decline in upholding democratic values. ${ }^{11}$

Trends include a variety of factors. Are these to be considered as causes or as constitutional rots? ${ }^{12}$ Constitutional crises ask whether constitutions can maintain their role of making politics possible by keeping struggles for power within politics and avoiding violence and civil wars. In contrast, constitutional rots and degenerations concern how constitutions degrade, leading towards authoritarianism and deadlock. Constitutional rots occur when government is exercised for the benefit of the few and not for the many. In the long term, this produces a loss of trust, political polarization, economic inequality, and governing failures. ${ }^{13}$

Besides such distinctions, if democratic interplay is agonistic by definition and if confrontational interpretations of the constitution are part of democratic life, then, what's wrong with political defeats or changes?

Must there be something more needed in order to speak of crises? For instance, to properly speak of crises, do these have to show evidence of erosion of institutional separation of powers, voting, fundamental rights etc.?

A different matter is what regards the dynamics of the crisis itself. If it is a crisis, is the crisis transitory as it is normally in constitutional democracies after 20 years? ${ }^{14} \mathrm{Or}$, is it structural and bringing a regime to an end? Is it erosion, backsliding, decline, or retrogression?

Some scholars have measured empirical counter-waves of democratic back fights and upheld the idea that democracies take more time to build than to destroy. ${ }^{15}$ Yet, this is a contested assumption. It is a rather widespread conviction that political degradation is much quicker and aggressive than the process of democratic construction. Where is the truth?

Consider attacks on secularism, abortion, freedom of expression, and assembly etc. How can we be sure that human dignity is safe? If human dignity is a constitutionally entrenched value, how can it be guaranteed against contemporary backlashes? Reflect on the following points: are they causes or just catalysts of deeper and longer processes of constitutional and democratic demise?

- Is representative democracy in crisis a result also of party crises? Since democratic parties have collapsed, democratic constitutionalism is also collapsing.

- Immigration and democratic ruling: does immigration challenge or bring about transformative constitutionalism?

- Religious resurgence: there are four tensions between religious talk and constitutionalism: (a) religious talks undermine civil liberties, i.e., LGBT and abor-

\footnotetext{
${ }^{10}$ See Freedom House (2019) at https://freedomhouse.org/sites/default/files/Feb2019_FH_FITW_2019_ Report_ForWeb-compressed.pdf. Accessed on 13.1.'21.

${ }^{11}$ See the World Value Survey at https://www.worldvaluessurvey.org/wvs.jsp. Accessed on 12.1.'22.

12 Graber (2018), 668.

${ }^{13}$ Balkin (2018), 18.

${ }^{14}$ See the findings at The Comparative Constitution Project at https://comparativeconstitutionsproject. org/. Accessed on 10.1.'22.

${ }^{15}$ In, Elkins (2018), 55 and 57-8.
} 
tion. (b) They are both structurally competing; they both compete to rule. (c) Religious movements enjoy transnational solidarity. (d) Exploitation of religious talk by populist politicians fuels social divisions. ${ }^{16}$ Religion is always somehow entrenched in liberal constitutions, sometimes explicitly, sometimes hidden. Can we say that with the resurgence of religious identity politics, we are moving from liberal to tribal constitutionalism?

- Unconstitutional constitutional reforms and resurgence of authoritarian ruling (as erosion of constitutional rights): a landmark illustration of this case is Hungarian Viktor Orban's right-wing populist amendment of the constitution. Resurgent populism opposes itself to democratic ruling as well as to democratic pluralism. ${ }^{17}$ Populism is widely responsible for unconstitutional transformations as in the case also of Venezuela with Chavez and Maduro.

- Economic inequality: are democracies endangered by global financial exploitative powers? Certainly, past EU adoption of the European Stability Mechanism (ESM) as a form of governance shows an overstepping of economic over political-constitutional powers. Institutions of economic globalization have reduced the liberty of citizens, and not only of the EU. Historically, constitutional arrangements deal differently with inequality: mixed constitutions (e.g., the Roman Republic as well as Gothic XVII sec.), for instance, created separate institutions for the plebs and the aristocracy. This can be observed in the Tribunes of the Plebs and the Senate in Rome for Machiavelli and the two Parliamentary branches in England for Locke. The goal was to create institutional ties for mutual checks. Minimal justice was considered as sufficient for the maintenance of social stability.

- Was juristocracy an appropriate answer to populist demands? No, for Hirschl, it confirmed the neoliberal interest of shielding markets from people's interests. ${ }^{18}$ For Graber, ${ }^{19}$ courts, particularly international ones, are the least plausible actors to realize cosmopolitan constitutionalism since they reflect the political trends of the people, and when they are as polarized as they are today, courts are conservative.

Are these models sufficient tools to prevent/restrain global capitalists from taking over the interests and actions of the state?

\section{One Step Forward and Two Backwards}

The three pillars upon which the liberal constitutional state has been constructed are collapsing: democracy, freedom, and constituent power (determining constitutional law). Nowadays, liberal constitutional democracies are incredibly complex machines

\footnotetext{
${ }^{16}$ On these points see Hirschl and Schachar (2018), 518.

17 See Werner-Müller (2016).

18 Hirschl (2004), 6-11.

19 Graber (2018), 687.
} 
facing problems of multi-ethnic integration, geographical diversity, overpopulation, and political confrontation.

The praise for a global market, the internationalization of human rights and constitutional values has promised a global extension of Western enlightenment values. However, today cosmopolitan liberalism and free market systems are showing insurmountable limits and paradoxes.

Modern liberal constitutional democracies arise out of the needs proper of the bourgeois man. Yet, current social and juridical perspective has moved beyond one defined by state parliaments. Has this new social dimension been unpaired by an inadequate level of democratic legitimacy, human rights, and constitutionally guaranteed freedoms?

The process of de-nationalization of the state has transferred state authority to non-state entities. International regimes, such as the WTO and the human rights regime, do not have state components even if they show some constitutional features. Furthermore, what was once the structuring of politically conflicting interests within parties is now left unbound (in the face of tremendous) forces confronting them internationally. Lack of democratic institutions as well as an international replica of the domestic analogy leaves the current cosmopolitan constitutional setting incomplete and far from directing political initiative.

I won't repeat here an old story, but I will, nevertheless, recall some problematic features of the process of globalization, or at least of regionalization of liberal constitutionalism as in the case of the EU. The problems regarding its democratic deficits are known to all, as well as its de facto constitutional turf as a result of the activism of its Treaties and of the Court of Justice of the European Union (CJEU). It is thanks to the Court that some basic constitutional-like principles have been forged, such as, the supremacy of EU law over member states' laws, as well as the principle of direct applicability of EU law. ${ }^{20}$ Some scholars have even spoken of an overconstitutionalization of the EU and pointed to all subsequent problems concerning the Kompentenz-Kompetenz capacity of member states to decide upon which powers to delegate and which to retain. ${ }^{21}$

Regarding the project of European integration, Weiler has moved the discussion on the democratic deficit of the EU forward by pointing to the betrayal of a messianic sort of legitimacy, that is, as the betrayed hope in a promised land that the EU originally communicated. ${ }^{22}$ This type of legitimacy was based on a dream like the one the EU provided: not so much one based on material or output legitimacy goods but one based on aspirations like that envisaged by the Schuman declaration. For Weiler, the dream collapsed because no democratic pedigree was embedded in the European project, and the economic crisis and the like prompted a sudden reversion of the EU project of unification.

The story might not be like that which Weiler describes, even if perceptively. It might be argued indeed that EU foundational messianism remained only an

\footnotetext{
${ }^{20}$ Originally, in the seminal cases of Van Gend \& Loos v. Netherlands (1963), Costa v. ENEL (1964), ECR 585.

21 See Grimm (2016), 307.

22 Weiler (2018), 637.
} 
ideological template, but failed to become both a constitutional project as well as a political and, therefore, a democratic project. This unfortunate outcome also accompanied national liberal democracies characterized by post WWII transformative constitutionalism. The latter has failed to deliver what it promised since the bricks upon which it was constructed-the party system-collapsed. For a number of reasons, both political parties and citizens' engagement with active, deliberative participation disappeared from the political scene.

Erosion of constitutional freedoms at the state level, in turn, was due not only to an internal weakness by states to control private companies, but also to the capacity of global financial powers to colonize EU governance and orient borrowing policies of indebted states in exchange for ultraliberal reforms. ${ }^{23}$

All in all, suprastate constitutionalism allowed, rather than impeded, a process of deconstituent deterioration. The result was a loss of legitimating normativity that was typical of liberal constitutionalism. Current absence of a post-(state) sovereignty constituent capacity depends largely on the absence of a post-national people. This resulted in softening the distinction between constitutional and statutory law with all the legal and political problems that followed therefrom.

\section{A Possible Way Out?}

Recall the theory of militant democracy. Militant democracy doctrine arose as a political strategy to contrast fascist and communist parties when its values were not yet entrenched in constitutions.

This was initially formulated by Loewenstein, a German Jew who sought exile in the USA after Hitler's seizure of power in Germany in 1933. ${ }^{24}$ Four years later, two articles appeared in The American Political Science Review under the title "Militant Democracy and Fundamental Rights" (I \& II). Here, the author claimed that democracy is entitled to defend itself when it considers that it has not yet accomplished its mission. Democracy must therefore turn "militant."

Loewenstein was worried about what he called the one-party or multiple-party authoritarian states that he saw spreading across Europe from the Baltic to the Southern European states. The seeds of such authoritarian politics were to be seen in the emotional methods of government oriented towards the mystification of the rationality of public interest and rule of law with private interests and opportunism. What he saw as the perils of fascist politics was not so much in its being an ideology but rather in representing a sophisticated technique_a Trojan horse_—as he called it, for parliamentary democracy.

For Loewenstein, democracy suffered from a congenital weakness. Indeed, by being a form of ruling constructed upon rational arguments, democracy remains incapable of responding to emotional politics by means of another emotional counter-argument. Thus, in Loewenstein's views, democracy had no other choice than to

23 See on this Corradetti (2020), 139-153.

24 Loewenstein (1937a), (b), I, 423. See also Loewenstein (1937a), (b), II. 
restrict the rights-protections of harmful discourses in order to protect the survival of the democratic process.

Here lies a paradox: how can democracy address itself to curtailing fundamental rights without wiping out its same justification? One might speculate on what would be a way out of this problem.

One option to solve the paradoxality of the militant democratic practice is by understanding its justification of fundamental rights with democratic self-legislation, rather than the shielding of the principle of self-determination through the restriction of its access to inimical forces. The paradox here would again only remain apparent since the restriction of the principle of equality would be limited solely to those cases wherein lack of intervention would compromise the very existence of democracy.

It might be objected that according to certain allegiance to radical democracy, no rights restrictions should ever be possible. This would apparently also solve the paradox by cutting the Gordian knot in the co-originality relation between the principle of democracy and the principle of human rights. However, here the solution is again only apparent because the foreseeable victory of authoritarian forces over democracy would generate an irreversible outcome. Rather than contribute to a solution, democratic fundamentalism, by allowing extensive right-protections to its internal enemies, would this time paradoxically contribute to the generation of the same conditions of democratic disappearance.

This is why the militant democracy principle should also be applied by considering the normative boundaries of the co-originality thesis in order to avoid paradoxical distortions.

For Loewenstein, extraordinary powers are limited to the transitional-stage only of democracy, namely, to the accomplishment of "the ultimate ends of liberal government: human dignity and freedom." ${ }^{25}$ Moreover, whereas legislative measures for the disempowerment of illiberal forces are necessary instruments in the safeguarding of democracy, they do not appear to be sufficient means for finally resolving the tension. As Lowenstein asserts: "no spiritual movement can, in the long run, be suppressed merely by legislative and administrative measures. At most, it may be only slowed up." 26

Here is the problem: how to stop illiberal ideologies from overcoming democratic forces? As he considered it to be simply a technique for exercising power, Loewenstein was wrong in thinking that fascism would not survive for long.

Yet, even now that fascism has been defeated, the problem remains also for a whole host of other illiberal ideologies (including populism) that turn out to be inimical to democracy.

How can we take from this lesson and suggest an expansion of the militant democracy strategy for current purposes?

This is a yet-to-be-explored pattern of reflection for future scholarship. As we do not want to lose the hard-won guarantees we have gained in the fight for our

25 Loewenstein (1937a), (b), II, 639 and 658.

${ }^{26}$ Loewenstein (1937a), (b), I, 431. 
liberal constitutional freedoms, we have to recognize the exceptionality of our times and the perils to which our fragile democracies are exposed.

Ruling democratically in times of emergency seems thus the new challenge for the XXI century.

\section{Declarations}

Conflict of Interest The author declares no competing interests.

\section{References}

Aristotle (1998 [IV sec.]) Politics, trans. C.D.C. Reeve, Hacket Publishing Company, Indianapolis, Cambridge, $\mathrm{Ca}$

Balkin J (2018) Constitutional crisis and constitutional rot. In M.Graber, S.Levinson, M.Tushnet (eds.), Constitutional Democracy in Crisis?, Oxford University Press, Oxford, 2018, 13-28

Comparative Constitution Project at https://comparativeconstitutionsproject.org/. Accessed on 10.1.'22

Corradetti C (2020) Hegemony critique and the crisis of the European Union. Jus Cogens 2(2):139-153

Elkins Z (2018) Is the sky falling? Constitutional crises in historical perspective. In: Graber M, Levinson S, Tushnet M (eds) Constitutional democracy in crisis? Oxford University Press, Oxford, pp 49-66

Freedom House, Freedom in the World 2018 (2019) The annual survey of political rights and civil liberties, Rowman \& Littlefield Publishers, Oxford. Available at: https://freedomhouse.org/sites/ default/files/Feb2019_FH_FITW_2019_Report_ForWebcompressed.pdf. Accessed on 13.1.'21

Ginsburg T, Huq AZ (2018) Defining and tracking the trajectory of liberal, constitutional democracy. In: Graber M, Levinson S, Tushnet M (eds) Constitutional democracy in crisis? Oxford University Press, Oxford, pp 29-48

Graber M, Levinson S, Tushnet M (eds) (2018) Constitutional democracy in crisis? Oxford University Press, Oxford

Graber M (2018) What's in crisis? The postwar constitutional paradigm, transformative constitutionalism, and the fate of constitutional democracy. In: Graber M, Levinson S, Tushnet M (eds) Constitutional Democracy in Crisis? Oxford University Press, Oxford, pp 665-690

Grimm D (2016) Constitutionalism. Past, present and future, Oxford University Press, Oxford, 2016

Hirschl R (2004) Juristocracy' - political, not juridical. The Good Society 13(3):6-11

Hirschl R, Schachar A (2018) 'Religious talks' in narratives of membership. In, M.Graber, S.Levinson, M.Tushnet (eds.), Constitutional democracy in crisis?, Oxford University Press, Oxford, 2018, 515-532

Judgment of the Court of 5 February 1963. NV Algemene Transport - en Expedite Onderneming van Gend \& Loos v Netherlands Inland Revenue Administration. Reference for a preliminary ruling: Tariefcommissie - Netherlands. Case 26-62

Judgment of the Court of 15 July 1964. Flaminio Costa v E.N.E.L. Reference for a preliminary ruling: Giudice conciliatore di Milano - Italy. Case 6-64

Loewenstein K (1937a) Militant democracy and fundamental rights I. Am Polit Sci Rev 31(3):417-432

Loewenstein K (1937b) Militant democracy and fundamental rights II. Am Polit Sci Rev 31(4):638-658

Loughlin M (2019) The contemporary crisis of constitutional democracy. Oxf J Leg Stud 39(2):435-454

McIlwain CH (1947) Constitutionalism ancient and modern. Cornell University Press, Ithaca and New York

Roznai Y (2017) Unconstitutional constitutional amendments: the limits of amendment powers. Oxford University Press, Oxford 
Schmitt C (1988) [1923] The crisis of parliamentary democracy. The MIT Press, Boston

Weiler JH (2018) The crumbling of European democracy. In: Graber M, Levinson S, Tushnet M (eds) Constitutional democracy in crisis? Oxford University Press, Oxford, pp 629-638

Werner-Müller J (2016) What is populism? University of Pennsylvania Press, Philadelphia

World Value Survey at https://www.worldvaluessurvey.org/wvs.jsp. Accessed on 12.1.'22

Publisher's Note Springer Nature remains neutral with regard to jurisdictional claims in published maps and institutional affiliations. 